\title{
The concept of Arabic Absorption Patterns in Indonesian and Malay Language
}

\author{
Makmur Haji Harun \\ Universiti Pendidikan Sultan Idris (UPSI)Malaysia \\ makmur@fbk.upsi.edu.my
}

\begin{abstract}
Arabic is absorbed into many other languages in the world, especially the majority of the Muslim population, and then melted into a speech language as a means of communication. Various Arabic terms are used in the communication of the high literary touches in accordance with the oral narrative including in Indonesia and Malaysia in particular and in Southeast Asia generally. The development of language in these two countries continues to expand its use so that it is no longer merely as an intermediate language but also the absorption of language used through literature, science, media, literature, Law, economics, social, art, Other cultures as the appreciation of the civilization of the local Islamic community, as well as its pattern, symbol and philosophy of life. There are many Arab removals that are entered and used in Bahasa Indonesia and Malay using certain patterns to facilitate the user to speak verbally and written. The purpose of this study aims to analyze the pattern of absorption of Arabic into Indonesian and Malay language in communicating as a fundamental proof of foreign uptake that underlies the height of philosophy and literature. The methodology of the study used is also developed through a library study with various forms of methods, theories and patterns as an easy channel to understand more fundamentally the form of theory and accounting. As the implication of this study is also expected to be the level and identity of the people of Indonesia and Malaysia which is reflected by language as the identity of the nation and state.
\end{abstract}

Keywords: Arabic, Indonesian, Malay, absortion, language, Southeast Asian

\section{Introduction}

The application of Arabic language that absorbs into various other languages in the world always melt into verbal and written language as a means of communicating with one another. Various Arabic terms have been used in communicating from the high literary touch results in accordance with the oral narrative including those used in Indonesia and Malaysia. The development of language in these two countries continues to expand its use so that it is no longer merely as an intermediate

AJIS : Academic Journal of Islamic Studies vol. 4, no. 2, 2019

IAIN Curup - Bengkulu | p-ISSN 2580-3174, e-ISSN 2580-3190

Available online: http://journal.staincurup.ac.id/index.php/AJIS 
language but also the absorption of languages received and used through intermediaries, scripture, religious discussion, The implementation of literature, the application of the law, economic intermediaries, art and culture developers.

The emergence of character changes are absorbed into the Indonesian and Malay language, evidenced by the role of Arabic Malay script or commonly also referred to as Jawi script. This ensures how much Arabic words influence in that language. When Islam is accepted as a religion that dominates the religion of the people in Southeast Asia, and there religion is an example of the body, it must be accompanied by its shadow, which is the Arabic language used in the matters of worship in particular and Communication language in general. While the Arabic is also realized application using bare Arabic script (written Arabic or Jawi). Thus, the major change in the civilization of the archipelago is the attitude towards Islam itself, being the historical roots and culture of the Islamic population in their respective territories.

While the Indonesian and Malay language continues to evolve, parallel to the change of the Arabic script was together with the writing. If researched carefully, there are many Arabic words that are absorbed into the Indonesian and Malay language that absorb into a speech language that is used as an intermediary communication for the community. In this case it is estimated that more than 2,200 words, it does not include the Arabic term that went into the vocabulary of today's globalization. As a rich and advanced language, we accept the arrival of these Arabic words to be used in the local language, either for the meaning of the first time or to add to the words of synonyms in vocabulary or usability Indonesian and Malay language communication.

For students who have never studied Arabic at all, or for teachers who teach these language lessons in order to get to know whether the word of origin in Bahasa Indonesia and Malay is originally Arabic or from other languages, should see Dictionaries that usually exist mentions the origin of a word, or more precisely refers to a dictionary of large English language or a Malay etymological dictionary. Often at the end of the word concerned is placed abbreviations as the word (A) or (AR); Meaning comes from the Arabic language. 
As for the emergence of a bald Arabic term in the Islamic community in Nusantara, it is likely because the use of Arabic writings that do not March but contain Malay writings that can be read and understood by Indonesians and Malaysians. Meanwhile, the term Arabic Malay, a term whose writings are derived from the Arabic letters but the content of Malay language. While the term Jawi is often associated with Arabic call to a national family in the archipelago. The Arabs think, all ethnic groups in Nusantara are from Java, and the inhabitants are called Jawi. According to Amat Juhari Moain (1996:17), the name Jawi is derived from the Arabic word Jawah. When it became an objective word, Jawah becomes Jawi. The word Jawah or Jawi is likely derived from the word Javadwipa, which is the name for the region in the Southeast Asian region in ancient times.

For the Arabs, the word Java is taken, while the word bilingual is abandoned. The word Java is used to refer to all regions in Southeast Asia. The inhabitants are also named using the word or in the form of objectivity to Jawi. Therefore, the word Jawah or Jawi refers to all nations and people who are indigenous to Southeast Asia, not only to Javanese people, namely people from Java Island. In contrast, Java or Jawi refers to all Malay people, regardless of whether they include Malays, Campa, Pattani, Aceh, Java, Minang, Mandailing, Sunda, Bugis, Dayak, Banjar, Lombok, Filipino and other nations.

This view was also supported by Muhammad Naquib al-Attas (1972:2) who stated that, "we know that the term Jawi is the name of the title of Arabs to all peoples of the island's population (Alam Melayu)". Arab Society anciently stretched out a nation in general based on the title of Land and its Earth. The tribes that inhabited the Earth were regarded as the same nation. For example, the African Earth is known as "Bilad alSudani" and the Tribes of Africa are known as al-Sudani. Therefore, it is not a fear that all of the Malay people are known as Jawi because the earth is known as "Bilad al-Jawah". Skin color factors, same body shape and language cause the Arabs of the past age classify the tribes concerned to a particular group of nations and races called "Al-Jawi".

The objectives of this study would like to analyze deeply the patterns of absorption of Arabic language absorbed into Indonesian and Malay language in communicating orally or written as a fundamental proof of the underlying foreign uptake Philosophy and literature. 
The method of study used in lifting the Arabic language is absorbed into the Indonesian and Malay language using a deepening analysis and comparisons which are also developed through the study by referring to several The library in support of the results of the study that has been carried out so that it becomes a conclusion that can be used by other researchers. In addition, studies are also conducted through studies in libraries with various forms of methods, theories and patterns as easy channels to understand more fundamental about the study being studied.

\section{Arabic Absorption in Southeast Asian languages}

In the early stage in southeast Asia, the writings were regarded as mystical and divine forces because it was considered a unique matter and not many of the people who mastered it. The realization of several kingdoms in Nusantara such as Sriwijaya, Majapahit, and Malay kingdom in pre-Islamic era requires a writing system to launch state government affairs and their Foreign relations. This happened because Sriwijaya was a large kingdom that depended on the seas and became the Maritime power. Thus, they had much to do with foreign communities through the Straits of Malacca and the South China Sea in trading affairs to launch their economies.

While the first stage of arrival of Islam to Malaya, which is approximately in the 12th and 13th centuries, Malay people did not create an instant Arabic or Jawi script. Instead, they need to use an existing Jawi script for the purpose of writing. The stone form of Terengganu inscription is an initial document evidence of the use of Malay Arabic writings in Nusantara. According to Muhammad Naquib alAttas, the inscription stone was written in $702(\mathrm{H})$, along with the year $1303 \mathrm{M}$. This inscription is the oldest Malay written stone with full Arabic script that can be seen until now. This oldest Malay manuscript marked $998 \mathrm{H}$ bersamaan $1590 \mathrm{M}$. The content of the inscription emphasizes the Fiqh law, also using old Malay Arabic writings, is a translation of the Book of Religion titled ' Aqa'id al-Nasafi. This evidence is used as a sign of real evidence of the existence of Arab Malay usage gradually from time to time.

Furthermore, since the Islamic religion began to tread in Nusantara, Malay Arabic writings began to develop and live with the community. 
According to historical records, this paper was first encountered in Malaya in the third century Hijri. This paper appears in line with the arrival of Islam to Indonesia in the first century Hijri. The arrival of Islam to Indonesia changed people's lives by abandoning animism practices and taking Islam as a way of life. The culture of science brought by Islam has issued them from ignorance to righteousness. Malay Arabic writings play an important role to support the development of Islam. The development and mastery of this writing in Indonesia and Malaysia have taken a long time because of the local people who have been with the belief of the influence of Hindu-Buddhist religion. However, the acceptance of Islam makes the locals can master the writing quickly.

Before the existence of this writing in the Malay World, it has actually appeared a form of the influence of the gods of the state used by the Pallava people in India and other countries such as South Sumatra, Campa, Ligor and Java. The evidence of Pallava's writings can be seen on the Kapor town inscription in Bangka, South Sumatra, which existed in the seventh century AD. In addition to the city of Kapor, there are also evidence of the use of Pallava writings such as Sajametra, Manju Shriga, Bukateja, Syang Hyang Winbtang and Dangpu Hawang Glis in the Indian region.

In addition to Pallava, there are other writings found in Sumatra, the inscription Rencong or Rencang. This paper is widely used in North Sumatra and South Sumatra regions such as Jambi, Bengkulu, West Sumatra and Tapanuli. This paper is used to record folklore, rules, customs, religious matters and other things. In the island of Java, there are ancient Javanese writings known as Kawi writings. The word Kawi derived from the word Sangsekerta means poet. This paper is widely used in Java with some adjustments, especially for producing Javanese literature.

Therefore, with the arrival of Arabic language which commonly became the principle of Arabic Malay script is associated with the religion of Islam. Although the arrival of Islamic religion to Nusantara still many different opinions, but there are some inscriptions as a strong evidence that shows that Islam existed in southeast Asia since long ago again. Among the evidence that shows Islam in Nusantara is the discovery of the tomb of Sheikh Abdul Qadir Ibn Husain Syah Alirah, in Langgar Alor Setar, 
Kedah, marked $290 \mathrm{H}$ simultaneously $910 \mathrm{M}$. There are also gravestones found in Pekan, Pahang day Wednesday 14 Rabi'ul Awal 429 H; Tombstone found in Phanrang, Vietnam marked $431 \mathrm{H}$ simultaneously $1039 \mathrm{M}$; And the gravestone of the daughter of Sultan Abdul Majid ibn Muhammad Syah al-Sulthan marked $440 \mathrm{H}$ concurrently $1048 \mathrm{M}$ in Islamic Cemetery, Jalan Residensi, Brunei Darussalam.

In addition, also found the gravestone of Fatimah Maimun bt. Hibatullah marked $475 \mathrm{H}$ at the same time $1082 \mathrm{M}$ in Leran Gresik, East Java. These inscriptions prove that Islam has long been tread in the Malay realm. In fact, this paper develops with the spread of Islam and managed to build a society with a culture along with Islam (Ismail Hussein, 1984). The spread of Islam by traders and the prosecution of the Malay Archipelago by using bahasaIndonesia and Melayu with his writings accelerated the development of Islam again. It is also demonstrated by the progress of the Islamic Malay Kingdom that was accomplished at the time of the Pasai Ocean. In the time of Malacca, all religious benefits were referred to the Samudra Pasai. The decline of Pasai in the early 16th century was replaced by the ACEH government. All the scholars and clever cleverly in the ocean Pasai were brought to the Kingdom of ACEH.

Even the writing activity of various literary materials continued there whose peak in the 17th century AD when the emergence of characters such as Hamzah Fansuri and Nuruddin ar-Raniri. Scholars and cleverly clever of Parsi also contributed a lot in the field of politics, trade, social, culture and religion of Islam itself, long time even the ocean Pasai famous as the center of Malay Language and literature development (T. Iskandar, 1995). The development in this field of literature is very rapid because the writing of literary works in Indonesian and Malay with the writing of Arabic Malay (Jawi) which at that time expanded widely not only in the community Even among the palace (Ismail Hussin, 1984).

There are many works in the field of literature and religion is published in the Malay text, so it is very influence of Bahasa Indonesia and Malay in all areas. As a result, the works of Malay history, Tun Sri Lanang, became one of the works of classical Malay history. This work is famous today and the reference to researchers and scholars. The Islamic kingdom reached its former glory until the 16th century AD at the same period, Malay Arabic script was fully used in government affairs in 
several Malay kingdoms in Nusantara. For example, in the reign of Sultan Muzaffar Shah Melaka (1455-1459 A.D.) and even the reign of Sultan Abdul Jalil Shah, Johor (1623-1677 M) Malay Arabic script was used on coins.

In the meantime, Islamic scholars in Malacca (1409 A.D.) have also used Arabic Malay writings as the language of speech and at the same time to write treatises on religion. Islamic literary works, such as Hikayat Amir Hamzah and Hikayat Muhammad Ali Hanafiah, have been translated into Indonesian and Malay sources of the original Parsi during the reign of Pasai. In addition, newspapers and magazines also use the writing, including Nujum al-Fajar (1872 A.D.), Jawi Peranakan (1876 M), Malay School (1888 M) and Majalahal-Munir which was published in Padang, West Sumatra. The use of Arabic Malay writings is also available in old and new currencies, such as those found in the paper currencies of Brunei Darussalam, China and Malaysia.

In addition to Malaya, these Arabic Malay writings also expanded beyond Southeast Asia such as Sri Lanka, Melayu Campa, Fattani and others. This happened because the Indonesian and Malay languages were used since the late 18th century by the Muslims there. In 1869 A.D., the Malay newspaper titled Address Langkapuri was published in Sri Lanka. Shaykh Ahmad Khatib and Muhammad Idris al-Marbawi and Syeikh Abdul Qadir al-Mandili were among the Indonesian scholars who studied in Makkah and Egypt and then wrote several books written in Arabic Malay.

In addition, the Malay script was also used by the merchants who came to Malacca and Semudera Pasai. This is true because traders need to get permission from the state officials to business in the place. Therefore, most of the permits and sales letters have been written using Arabic and Arabic Malay script. Examples, such as the permit from Sultan Ala'uddin ACEH to Captain Henry Middleton who was marked 1011 H/1602 M. In addition, there is also a letter from the Sultan of Aceh to an English captain who is marked $1011 \mathrm{H}$. And many other examples of this role and the use of Arabic Malay writings are evenly located in Nusantara.

\section{Arabic Malay Language and Writing Form}


The letter of Malay, also known as Jawi, has 37 letters. The number of letters exceeding the Latin alphabet causes not all of the Malay characters can be equated with the Latin alphabet. The Malay Arabic alphabet starts from the Alif letter and ends with the letter. There are six additional letters created by the Malay scholars to complement the emblem of Indonesian and Malay sounds. The following are Arabic Malay letters according to the order.

\begin{tabular}{|c|c|c|c|c|c|}
\hline ₹ & ج & $ث$ & ت & ب & 1 \\
\hline j & נ & $\dot{j}$ & د د & $\dot{\tau}$ & $\tau$ \\
\hline ظ & ط & ض & ص & ش & س \\
\hline ق & ث ث & ف & $\dot{\varepsilon}$ & $\dot{\varepsilon}$ & $\varepsilon$ \\
\hline و & ن & م & $J$ & ك & S \\
\hline ث & ى & ي & $\&$ & هـة & ف \\
\hline
\end{tabular}

The use of Malay script is the same as the Latin alphabet. This script has 37 letters consisting of 3 vowels and 33 consonants. Originally, the Arabic alphabet was derived from the Arabic alphabet which has 30 alphabets, including the letter $\mathrm{Ta}$ ' Marbutah ( $(\dot{)})$. However, these letters are not able to meet the spelling of Indonesian and Malay language. In doing so, in order to align Arabic Malay writings with Indonesian or Malay spelling, Malay people have added five more letters to represent the original sounds in Indonesian language or the sound of the people.

The letters are $c a(₹)$ which is matched with the letter C, $n g a$ ( $)$ )letter which is matched with the letter $\mathrm{Ng}, p a(\omega)$ letter that is matched with the

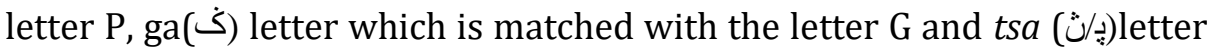
which is matched with the letter NY. Next, in 1986 according to the book The Perfected Jawi Spelling Guide (PEJYD), it isadded another letter, wa letter ( $\dot{)}$ ) to represent the sound $w$. That is why the number of Malay letters is increasing to as many as 37 letters.

\section{Main Malay Alphabet (Vocals)}

In Arabic Malay, there are three main letters which are also called vowels, which are the Alif ('), producing the sound alike in the wordayah. The second letter is wau (g), it sounds $u$ like in the word udang. The third vowel letter is $y a$ (ي), it sounds $i$ like in the word ikan. These three letters represent a six-letter Latin vowels like: The alif represents the vocalsain 
general and $a$ at the beginning of word, the letter wau representing the vocals $o$ and $u$ in the middle and end of word, the letterya representing the vocals $i$ and $e$ at the middle and end of the word.

However in the initial position of the word wau (g), this letter can not sound $u$ without being assisted by the letter alif $(')$. The letters of alif-wau can then produce a sound $u$. For example, the word shrimp will be spelled likeudang (غاود). Likewise with the letter ya (ب),this letter is also not able to produce the sound without being assisted by the letter alif ('),alif-ya. Example, the word fish is spelled ikan (ايكن).

\section{ConsonantLetter}

In addition to the three main vowels, in the Malay text system there are 33 consonants, letters other than the Alif letters, Wau and yes. This consonant is divided into two groups. The first group consists of 18 letters and is used to write original Indonesian or teak Malay words. Among the letters are the letter(ب), ta(ت),jim(ج), dal(د), ra (ر), syin(س),

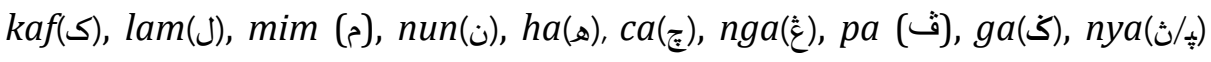
andhamzah(s). The second set of letters is the letter used to spell and to write Arabic words and terms. They are the letter tsa( $\dot{(}), h a(\tau), k h a(\dot{z})$, zal(ذ), zai(j), syin(ش), shad(ص), dhad(ض), tha(b), za(ظ), ain(ع), ghain(غ) dan huruf $f a(ف)$, dan qaf(ق) (Muhammad Bukhari Lubis dan Ali Haji Ahmad, 2006).

\section{Indonesian and Melay Modified Letters}

The Arabic letters are generally derived from Arabic letters or also known as Hijaiyah letters, which are 30 letters of Arabic letters. However, these letters are not able to complement most symbols of speech in English and Malay language. Therefore, earlier scholars have taken the two changed letters according to Parsi, namely $c a$ and ga; In addition to the Malay scholars themselves have a few new letters such as nga, $p a$, nya and $v a$. The six letters use the "House of letters" already in Arabic Hijaiyah letters, but are changed accordingly by adding points to certain sections, such as the following example:

\begin{tabular}{|l|c|}
\hline Ha $(\tau)$ & Ca (๕) \\
\hline
\end{tabular}




\begin{tabular}{|c|c|}
\hline Ain $(\varepsilon)$ & Nga( \\
\hline $\mathrm{Fa}(\dot{\omega})$ & $\mathrm{Pa}(\dot{\theta})$ \\
\hline Kaf(ك) & Ga (ذ) \\
\hline Nun \& Ba (ب) & Nya ( \\
\hline Wau (g) & Va (j) \\
\hline
\end{tabular}

Selain itu, terdapat juga huruf baru yang dipadankan dengan huruf v, dinamakan va (j), wau bertitik dan huruf ye (⿶), istilah leweh berarti imalah ataue-taling (é) ya tanpa titikatau alif al-maqsurah dalam bahasa Arab yang dipadankan dengan huruf e-pepet (a) di akhir kata pada perkataan-perkataan tertentu seperti nasionalisme(ناسيوناليسمى) dan metode (ميتودى).

In addition, there are also new letters that are matched with the letter $\mathrm{v}$, named va (j), Dotted wau and letter ye (s), the term Leweh means assimilation or e-taling (é) letter ya without dots or alif al-aaqsurah in Arabic which is matched with the letter e-Pepet (a) in the end of word on certain words such as nasionalisme (ناسيوناليسمى) and metode (ميتودى).

\section{Latin Letters and Their Equivalent with Malay Arabic letters}

Malay Arabic letters have alphabetical numbers more than Latin letters. Therefore, the equivalent of all letters with Latin letters is not one on one, but there is one on two or one on three and so forth. The description is as follows.

1. There are only 18 Malay Arabic letters which have these Latin single-letter equivalents and are recognized as teak-equivalent equivalents.

\begin{tabular}{|c|c|c|c|}
\hline [p] & ق & [b] & ب \\
\hline [q] & ق & {$[\mathrm{t}]$} & ت \\
\hline$[\mathrm{k}]$ & ك & [j] & ج \\
\hline [g] & ك & [c] & ₹ \\
\hline [l] & J & [d] & د د \\
\hline$[\mathrm{m}]$ & م & [r] & J \\
\hline [n] & ن ن & {$[\mathrm{z}]$} & j \\
\hline [h] & هـ & [s] & س \\
\hline [v] & ف & [f] & ف \\
\hline
\end{tabular}


2. In addition to the equivalent of teak letters, there is also a combined equivalent, that is, one Malay Arabic letter paired with two Latin letters. There are 5 Malay Arabic letters using this type of equivalent in Latin spelling which now has a digraph (twoletter) equivalent of Latin, such a equivalent is like the letter ghain ( $\dot{\xi}$ ) paired with the letter [gh], the letter syin (ش) paired with the letter [sy ], the letter kha $(\dot{\zeta})$ which is paired with the letter [kh], the letter nya which is paired as the letter [ny] and the letter $n g a(\hat{\xi})$ which is paired as the letter [ng].

3. There is also a Malay letter that does not have a teak equivalent of the Latin alphabet because of the different word with the Latin alphabet. There are 14 letters that have Latin equivalent in more than one letter. The letters such as the letter s for $ص$, sy and sh

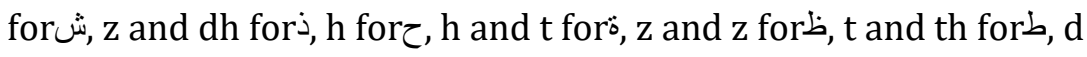
and dh for ض, w,o and u for $9, \mathrm{q}$ and k for $\mathrm{a}, \mathrm{k}, \mathrm{o}, \mathrm{u}, \mathrm{e}, \mathrm{i}$ and a for, $\mathrm{k}$ fors, th and s for $ث$, e and a fors, and y,e and i fors.

\begin{tabular}{|c|c|}
\hline Tsa (ث) & $\begin{array}{l}\text { The sound of the letter tsa }(\circlearrowleft) \text { in Malay speech or tongue } \\
\text { is close to the sound of the letter syin (w), then this letter } \\
\text { is paired with the letter [s] }\end{array}$ \\
\hline Zal (ذ) & $\begin{array}{l}\text { The sound zal (j) is almost similar to the letter zai (j), so } \\
\text { this letter is paired with the letter [z] }\end{array}$ \\
\hline Shad (ص) & $\begin{array}{l}\text { It reads almost with syin (w) then the letters shad (ص) } \\
\text { and syin }(\omega) \text { are paired with the letter [s]. }\end{array}$ \\
\hline Dhad (ض) & $\begin{array}{l}\text { The sound of the letter dhad (ض) is in the middle of the } \\
\text { sound of letters dal-shad, which is more to the sound of } \\
\text { dal (د) then this letter is paired with the letter [d]. }\end{array}$ \\
\hline Tha (b) & $\begin{array}{l}\text { Because it sounds more or less the same as the letter }[t] \text {, } \\
\text { but is only called bold, this letter is actually paired with } \\
\text { the letter [t]. }\end{array}$ \\
\hline Zha (ظ) & $\begin{array}{l}\text { The sound of zha is similar to the pronounciation zai (j) } \\
\text { like dal (د) with dhad (ض), syin (س) with shad (ص), ta (ت) } \\
\text { with tha (b), this letter is paired with letters [z]. }\end{array}$ \\
\hline Ain (ع) & $\begin{array}{l}\text { The place where the letter ain }(\varepsilon) \text { is close to the letter alif } \\
(1) \text {, only called rather nasally (sounds to the nose), then } \\
\text { this letter is paired with the letter [a] if it is present at the } \\
\text { beginning of the word. If you are in the middle or at the } \\
\text { end of a word, the letter ain }(\varepsilon \text { ) is paired with the letter } \\
\text { [k], which is the sound of a glottis stop. }\end{array}$ \\
\hline
\end{tabular}


4. The whole letter of the Malay alphabet has the equivalent of the Latin single letter.

\begin{tabular}{|c|c|c|c|}
\hline $\begin{array}{l}\text { Latin } \\
\text { letter }\end{array}$ & $\begin{array}{l}\text { Malay } \\
\text { Letter }\end{array}$ & $\begin{array}{l}\text { Latin } \\
\text { letter }\end{array}$ & $\begin{array}{l}\text { Malay } \\
\text { Letter }\end{array}$ \\
\hline $\mathrm{Aa}$ & 1 & $\mathrm{Aa}, \mathrm{Kk},(\mathrm{\prime})$ & $\varepsilon$ \\
\hline $\mathrm{Bb}$ & ب & Gh (gh) & $\dot{\varepsilon}$ \\
\hline $\mathrm{Tt}$ & $ت$ & $\mathrm{Ng}$ & $\hat{\varepsilon}$ \\
\hline $\mathrm{Hh},(\mathrm{t})$ & $\ddot{0}$ & $\mathrm{Ff}$ & ف \\
\hline Ss, (th) & ث & $\mathrm{Pp}$ & ث \\
\hline $\mathrm{Jj}$ & ج & $\mathrm{Kk},(\mathrm{q})$ & ق \\
\hline $\mathrm{C}$ & ש & $\mathrm{Kk}$ & $s$ \\
\hline Hh (h) & $\tau$ & $\mathrm{Gg}$ & $\dot{5}$ \\
\hline Kh, kh & $\dot{\tau}$ & $\mathrm{Ll}$ & J \\
\hline $\mathrm{Dd}$ & د & $\mathrm{Mm}$ & 5 \\
\hline $\mathrm{Zz}(\mathrm{dh})$ & $\dot{j}$ & $\mathrm{Nn}$ & ن \\
\hline $\mathrm{Rr}$ & J & $\mathrm{Ww}, \mathrm{Oo}, \mathrm{Uu}$ & 9 \\
\hline $\mathrm{Zz}$ & j & $\mathrm{Vv}$ & j \\
\hline Ss & س & $\mathrm{Hh}$ & 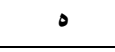 \\
\hline Sy (sy) & ش ش & $\mathrm{Kk},\left({ }^{\prime}\right)$ & 4 \\
\hline Ss (s) & ص & Yy, Ii, Ee & ي \\
\hline $\mathrm{Zz}$ & ض & $\mathrm{Ye}$ & $\checkmark$ \\
\hline $\mathrm{Tt}(\mathrm{t})$ & $b$ & Nya & ث \\
\hline $\mathrm{Zz} \mathrm{(z)}$ & & & ظ \\
\hline
\end{tabular}

\section{Analysis of key principles of Arab Absortion Concept in Indonesian and Malay Language}

In principle, it can generally be said that Arab removals can be spelled by following methods that go beyond the law and violate certain methods. That is, most of these words are outside the spelling method that has been learned, especially when compared to how to spell the original Indonesian and Malay teak. Example:

$$
\begin{aligned}
& \text { Fardu - فرض = Garpu (خرقو) }
\end{aligned}
$$

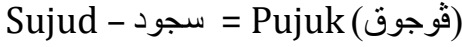

$$
\begin{aligned}
& \text { Zaman - زمان = Makan (ماكن). }
\end{aligned}
$$

Two Great Division Principles 
There are two main principles in the matter of spelling the Arabic word, namely:

1 The term religion retains his spelling. Arabic adjectives which belong to the ' religious term ', or perceived as a special term, must be retained by his (there is also the exception, in another discussion). Example: kitab - كتاب, nikah - نكاح, wudhu' - وضوء

2 The common words that are in common the words of the word are not religious terms and the term is long absorbed so it is spelled according to the spelling of the word teak in Malay and is the original word in the Indonesian language. Example: kertas =

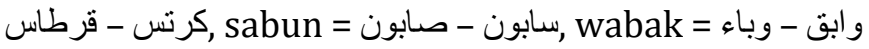

\section{Other Detailed Methods and Descriptions}

1. Spelling changes although the term

Although one word is a term, but to avoid homographs, i.e. two words that are the same spelling but different sounds and meaning, then there is a term that changed the spelling (the addition of letters especially vocal). The vowel in the Indonesian/Malay language is to guide the actual sound (up [a], forward [u], or down [i]). In Arabic, however, the vowels function to lengthen the sound of the letter, with certain conditions, even the time, because the difference between the short readings with the long readings, has given different meanings.

\begin{tabular}{|c|c|c|c|}
\hline $\begin{array}{c}\text { Arab } \\
\text { Spelling }\end{array}$ & First Sound & Second Sound & $\begin{array}{c}\text { Arabic Malay } \\
\text { Spelling }\end{array}$ \\
\hline \multirow{2}{*}{ ذكر } & \multirow[b]{2}{*}{ (zikrun) } & (Zakrun) & ذكر \\
\hline & & (Zikir) & ذيكير \\
\hline \multirow{2}{*}{ عالم } & \multirow{2}{*}{ (Alam) } & & عالم \\
\hline & & (Alim) & عاليم \\
\hline \multirow{2}{*}{ محرم } & \multirow{2}{*}{$\begin{array}{c}\text { (Mahram) } \\
\text { (Muharram) }\end{array}$} & & محرم \\
\hline & & (Muhrim) & محريم \\
\hline
\end{tabular}

2. Even long absorbed (the common word) yet arabic spelling preserved

There is a word in this group, although it has long been absorbed, the original spelling of the source language was preserved. Example:

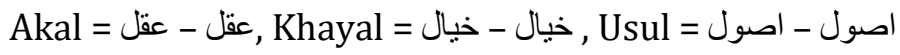


3. Common words that accept special consonant changes

There are words that changed the letters of the consonant, especially Arabic consonants teak, in order to facilitate his speech in Bahasa Indonesia and Malay. Example: Aral = كراف سيل - خلاف = كامير Silap

4. No vocal on religious terms but plus vocals for common sense

There are religious terms spelled without vowels despite the vocal sounds [a], [i] or [u]; However, when it is used for general understanding, added the letters alif, ye or wau. Example: Arif = عاريف, Al-Hakim = الحاكم

5. As an eternal word of origin spelling there is adding when it becomes a word publication

The word ending with an open syllable using a vowel [a], [i] or [u] should be spelled according to its origin as a base word. If it is formed into a word, with an additional suffix or particle, it is necessary to add an alif, ye or wau in order to avoid a mistake in the reading. Example: Fardu - Memfardukan = فرض - ممفرضوكن, Haji - Menghajikan = فتوى - ممفتو اكن = Fatwa - Memfatwakan , حج - مغحاجيكن

6. Added vowel letters to the original consonant words only

For the sake of avoiding mistakes or errors in reading vocal sounds, the vowels of yes or Wau are added to the Malay Arabic spelling. Example: Fikir = فيكير - فكر, Rukun = روكون - ركن, Umur = عمر عمور

7. A change of the letter alif maqsurah in Arabic (undotted letterye) becomes an Alif

As the basic word again, it continues to be changed yes that does not dot it into an alif because it has long been absorbed and not the term. Example: Dakwah = دعو | - دعوى , Makna = معنى - معنى

8. The keeping of alif maqsurah in Arabic (ى, i.e. ye no dotted), but modified when receiving the suffix.

There is an Arabic uptake word that maintains this letter, which in Malay Arabic spelling is called ye (e-pepet). Example: Fatwa = فتوى - فتوسى Musa = موسى - موسى, Takwa =قىى - تقوى 
However, when it becomes a word with the suffix or particles, the letteralif maqsurah or ye is replaced with an alif letter anyway.

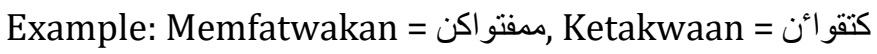

9. Spelling retention as the term changes when it becomes a common word.

There is an Arabic uptake word that accepts both functions as common terms and words. As a term, it retained its original spelling. As a general word, it is to be changed where it is necessary. The meaning is a little wider, not tied to the boundaries or elements of the

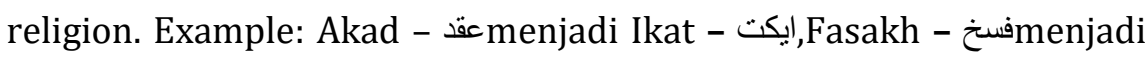
مisah - فيسه

10. The writing of the letter hamzah

In Arabic there are four places that the letter hamzah has placed, namely: without a house, the character of the letter alif (above or below the alif), the letter wau and the letter in the house of ye. For the word absorption that is not a term of religion, the word removals is spelled according to the method of spelling the Malay and original Indonesian teak, namely by placing Hamzah after Wau, not the Hamzah said Wau (there is a hallway and three quarters of the line). Example:Mutamar - Mu'tamar $=$ مو تَمر, Mukmin - Mu'min = مو من

\section{Writing of the Letter Ta Marbutah (Ta knot)}

In Arabic shavings, the letter Ta Marbutah that serves only solely at the end of one-on-one word represents the sound $[\mathrm{t}]$ or $[\mathrm{h}]$ as a deformity, and the deformity often does not distinguish meaning. In the Indonesian or Malay admission, there are three kinds as follow:

a. Received as a sound [ $\mathrm{t}$ ] then written with the spelling $t a(-)$ (ta maftuhah or longta). Example: Dahsyat - dahsyat = دهثت Musyuarat-Mu.syua.rat = مشوارت, Surat - su.rat = سورت

b. The sound [h] with the spelling of ta marbutah (i). Example: Fathah - Fat.hah = فتحة, Madrasah- Mad.ra.sah = مدرسة, SurahSu.rah

c. The sound[t] and [h] with the spelling of ta marbutah (i). Example: Akibat/akibah - a.ki.bat/a.ki.bah Hidayat/hidayah هداية, Musibat/musibah-mu.si.bat/ mu.si.bah =مصيية 
In general, the words in this group are spelled out according to their acceptance patterns into Indonesian and Malay language in Nusantara.

\section{The concept of the Arabic Absortion Pattern in Indonesian Language}

The most widely absorbed word is from the word class of the name. The word name includes several sub-classes, namely ism fa'il (the name of the perpetrator), ism maf'ul (name of the object), ism masdar (the name of the derivation), ismmakan (name of the place), ism zaman (the name of the time) and ism alat (the name of the instrument).

The word name is based on the Arabic verb form. There are 10 types of verbs. According to traditional Arabic studies, the verb is divided into: al-mujarrad al-thulathi (the root consists of three human letters), almazid bi'l-harf (additional letter to the three human letters), al-mazid bi'lharfaen (additional two-letter to the three human capital letters) and almazid bi thalathah ahruf (additional three letters to the three human letters). To make this division easier, it is necessary to use divisions or other terms, such as the following descriptions.

Verb Vorm I (fa'ala/fa'ila/fa'ula).

The verb form I or thebasic form consist of six patterns: (1) a-u (nasara yansuru), (2) a-i (daraba yadribu), (3) a-a (fataha yaftahu), (4) ia ('alima ya'lamu), (5) u-u (karuma yakrumu) dan (6) i-i (hasiba yahsibu).

In Arabic absorption words into Indonesian and Malay, there are six names that appear from the verb form I, they are:

1. Ism fa'il (name of prepetrator)with the patternfa'il (فاعل).

a. as a general word, plus the letter yes for the final closed syllables. Example: Sa.lim - Salim = ساليم - سالم, 'A.dil - Adil = عاديل - عادل dan Ha.kim - Hakim = حاكيم - حاكم.

b. When it became a religious term retained its Arabic spelling. For example, the name or nature of God, specifically a personal name beginning with the word ' $A b d$. Contoh: Ha.fiz ['Abd] al-Hafiz= عبد) الحافظ-حافظ) dan Sa.lim - ['Abd] al-Salim = (عبد) السالم 
c. The spelling of the words plus the letter ye at the end of the word. It is applied to the Arabic verb which the third letter is the letter ye (i.e. belonging to the verb mu'tal). Example: Da.'in- Da.'in =اعي-داض_an Qda.din - Kadi = قاض

d. Ism fa'il (the name of the perpetrator) of the pattern fa'il (فعيل) and fa'al (فعل). He retained his Arabic spelling. Mostly it becomes a personal name (including the name or nature of God). Example: Ka.rim - Karim = كريم - كريم, Sya.rif - Syarif = dan Ha.san - Hasan = شريف - شريف - شريف

2. Ism maf'ul (the name of object) in the patternmaf'ul (مفعول) only.

It can be said uniform, and incidentally the original Arabic spelling along with the method of spell Malay teak.Example: Ma'. lum - Maklum = معلوم - معلوم, Mak.tub - Maktub = مكتوب - مكتوب dan Masy.hur - Masyhur = مشهو - مشهور

3. Ism masdar (the nounof derivation).

a. Ism masdar in the patternfi'alat (فعالة).

The word consists of three syllables and ends with the letter ta ' marbutah. There are some guidelines to note:

1) according to the original spelling (in Arabic), the vowel [i] in the syllable is first spelled without using the vowel as a symbol. It is so steady in the use of Malay Arabic spelling. So it (without adding the letterye) remains retained.

2) there are four things that apply to the last letter of the group's words, namely ta' marbutah, namely: (a) accepted as $h a$, (b) accepted as $t a^{\prime}$, (c), accepted as ha and $t a^{\prime}$ in exchange without change of meaning, and (d) accepted both but experience an extension of meaning: acceptable as $h a$ and eternal with the meaning of its origin; or accepted as $t a^{\prime}$ with a new meaning and distinct from its original meaning.

In addition, there is a special method to spell based on the fourth four type, namely: (a) Ta'marbutah letters are converted into $h a$, (b) the letter $t a^{\prime}$ marbutah is exchanged with $t a^{\prime}$ maftuhah ( $)$ ), (c) the letter $t a^{\prime}$ marbutah is retained, and (d) the letter $t a^{\prime}$ Marbutah is converted into ha or $t a^{\prime}$ maftuhah according to the meaning of each. Example: 'I.ba.rat 
- Ibarat = عبارت - عبارة, Ri.wa.yat - Riwayat = حكابة dوايت- رواية dan

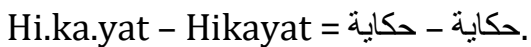

b. Ism masdar in the pattern fa'al(فعلة (ف)

Since the beginning is spelled according to the Arabic spelling, the spelling of the words has also been steady. Then there is no change. Example: Na.sab - Nasab = نسب - نسب, Bahts/Ba.hats - Bahas = بحث - بحث dan Qa.dar/Ka.dar - Kadar قدر - قدر

c. Ism masdar in the pattern filat (فعلة).

If it becomes a term, the spelling of the original language is retained. Although it has become a common word, but because the word has been steady with its original spelling, it is retained spelling in Arabic. The general word is often written or spelled according to the Arabic Malay method. Example: Jiz.yah - Jizyah = جزية - جزية Fit.nah - Fitnah = فتية - نتنة فتنه dan Ni'.mat - Nikmat = نعمت - نعمة.

d. Ism masdar in the pattern fi'al (فععال نعمد).

The spelling of the word in this group has also been steady according to its Arabic spelling, so it was preserved. Example: Ji.had - Jihad = جهاد - جهاد, Hi.sab - Hisab = حساب - حساب dan

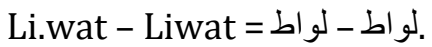

e. Ism masdar in thepattern fa'al (فعال).

It has been steady as its original spelling, so it continues to be preserved. Example: Ha.lal - Halal حلال - حلال, Q حقام - Q = قرار - فرار dan Ma.qam -Makam= فقام - مقام.

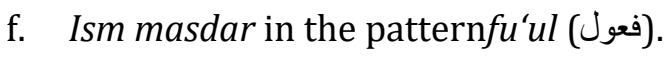

The already steady spelling, according to the Arabic spelling, remains preserved. Example: Ru.ku' - Rukuk = ركوع - ركوع, Su.jud - Sujud = سجود - سجود dan Syu.ruq - Syuruk = شوع -

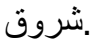

g. Ism masdar in the patternfa'alat (فعالة).

Also spelling words in this group has long been steady as the spelling of the original language, so it is still retained. Example :Qa.na.'ah - Qanaah = قناعة - قناعة, Qa.ra.bat - Kerabat dan Sya.fa.'at - Syafaat = قر ابة - قرابة

4. Ism makan (the nameof place). 
There are two possibilities for this word name, either the pattern maf'al (مفعل) or maf'il (مفعل).

a. Based on the a-u verb pattern, it will be mafal (masculine) or maf'alah (femimin). The spelling of these words coincidences are similar to how to spell the original Indonesian word and teak Malay, so it remains retained. Example: Mah.syar Mahsyar = محشر - محشر, Mar.kaz - Markaz = مركس - مركز and Mad.ra.sah - Madrasah = مدرسه - مدرسة

b. Based on the verb pattern a-a, it will be maf'al (مفعله مدلهد).Similarly, with the way of spelling of Indonesian and teak, the original spelling did not accept any changes. Example: Madh. hab Sect مذهب, Madh. Bah - Mazbah = مذبح - مذبح and Ma '. Mal Makmal = معمل - معمل

c. Based on a pattern verb a-i, it will be maf'il (مفعلدمع).If it became a common word, plus the letter ye for the final closed syllables. Example: Maj.lis - Majelis = مجليس - مجلس.

d. Based on a pattern verb a-i, it will bemaf'il (مفعيل). If it is a term or a general word but has long been steady according to its origin, then it is retained spelling in the Arabic language. Example: Magh.rib - Maghrib = مغرب - مغرب, Mas.jid - Masjid = dan Mash.riq - Masyrik = مسجد - مسجد - مشرق مغرق مشرق

5. Ism zaman (the name of time).

Only one possibility, it is the pattern maf'il (مفعل). Because it has been steady with the spelling of the word of origin, it continues to be retained, not changed according to the spelling of the original Indonesian and Teak Malay. Example: Magh.rib - Maghrib = مغرب مغرب.

6. Ism alat (the name of tool).

There are two possibilities, either the pattern mif'al (مفعل) or mif'al (مفعال). It can be concluded various forms. In general, the words in this group are terms that contain special meaning, so the original spelling remains retained. It should not be based on how to spell the original Indonesian and teak Malay words. Example: Mim.bar Mimbar = منبر - معراج - معراج = منبر dan Mih.raj -Mikraj Mihrab = محر اب - محر ابر منبر. 
Verb Form II (fa"ala)

This form II verb gives three types of word name in Indonesian and Melayu language, namely:

1. Ism fa'il (name of the perpetrator), only in the mufa"all pattern (مفع).

The spelling of the original word is preserved. However a bit unfortunate a little because the Latin spelling has already dropped one of the third letters. The third letter of the publication is marked as Syaddah (double). If it is Dilatinkan, the letter should be written twice. One miscarriage resulted in the reader being incorrectly called. Example: Mu. Bal. ligh - Mubaligh = مبلغ - مبلغ Mu. FAs.sir - Mufasir = مفسر - مفسر and Mu. Taw. wif - Mutawif = مطوف - مطوف.

2. Ism maf'ul (name of the object), only in the pattern mufa"al (مفعل). Most words in this group are common words. From the beginning he used the spelling of his source language, so he became steady. Then the original spelling was forwarded. The words in this group also in the record with the Latin Alphabet had suffered one of the letters marked with a Syaddah. Example: Mu.sab.bab - Musabab = مسبب - مسبب, Mu.kal.laf - Mukalaf = مكلف - مكلف dan Mu.kar.ram Mukaram = مكرم - مكرم.

3. Ism masdar (the nounof derivation).

a. the nounof derivation in the pattern fa'il (فعيل), derived from the work of the letter consonant or more precisely no vowel yes at the end ( $f^{\prime} l \mathrm{mu}$ 'tal). Incidentally, the word in this group follows a method of Arabic Malay spelling. The original spelling was continued. Example: Tab.ligh - Tabligh = تبليغ تبليغ Taf.sir - Tafsir = تفسير - تفسير and Tas.bih-Tasbih = تفبيح تسبيح.

b. the nounof derivation in the pattern of taf'ilah (تفعلة) (feminine), derived from the verb which is all consonant or a vowel $y e$ at the end ( $f^{\prime} l \mathrm{mu}$ 'tal). Incidentally, the word in this group follows a method of Arabic Malay spelling. Then it continues the spelling of the original. Examples: Tadh.ki.rah Tazkirah = هنكر - تذكرة, Tar.bi.yah - Tarbiyah = تربيه - تربية and Taz. ki.yah - Takziah = تعزيه - تعزية 


\section{Verb Form III (fa'ala)}

This verb form III gives three types of word name in Bahasa Indonesia and Melayu, namely:

1. Ism fa'il (the name of the perpetrator) only in the pattern of mufa'il (مفاعل).

a. For the word that has been properly absorbed, it is spelled by adding the letter ye to the final closed syllables. Example: Mu.sa.fir - Musafir = مسافير - مسافر

b. For the word that is a common term or word that has not been absorbed correctly, it is spelled without adding the letter ye to the final closed syllables. Example: Mu.ja.hid-Mujahid = مجاهد - مجاهد, Mu.ha.jir-Muhajir = مهاجر - مهاجر dan Mu.na.fiqMunafik = منافق - منافق

2. Ism maf'ul (the word object name) only in the pattern mufa'al (مفاعل). For the word this group should be spelled as in the source language. Example: Mu.ba.rak - Mubarak= مبارك - مبارك, Mu.ha.jatMuhajat = محاجة_محاجةdan Mu.'a.had - Muahad= معاهد - معاركد.

3. Ism masdar (noun of derivation), only in the patternmufa'alat (مفاعلة).

The words belonging to this group should be spelled as in the source language. Example: Mu.sa.ba.qah-Musabaqah= مسابقة مسابقه dan Mu.da.ra.bah-Mudarabah = مضاربه-مضاربة da.ha.dahMujahadah = مجاهده - مجاهدة.

\section{Verb Forms IV (af'ala)}

This form IV verb gives three types of word name in Indonesia and Melayu language, namely:

1. Ism fa'il (name of the perpetrator) only in the mufa'a'l pattern (مفع).

a. For the term word, this word is spelled by the spelling of the source language. Examples: Mus.lim-Muslim = مسلم - مسلم, Musy.rik- Musyrik = مشرك - مشرك and Mur.syid-Mursyid = مرثل مرشد

b. For the words that are absorbed correctly in the Indonesian and Malay language so that it changed the word according to the sound of both languages; Or being a term, but inflicting a mistake with another word of absorption different from the 
sound but spelling the same origin, it needs to be spelled by adding the vowel letter to the final closed syllable. Example: Mung.kin-Mungkin = مو غكين-ممكن and Muh.rim-Muhrim = محرم - محريم.

2. Ism maf'ul (Word object name) only in the pattern muf'al (مفعل). Although the words in this group are many common words, they do not change, according to the spelling of the source language. Examples: Mun.kar-Mungkar = منكر - منكر, Muf.rad-Mufrad = مفرد مفرد and Mut.laq-Mutlak = مطلق - مطلق = منكر.

3. Ism Masdar (the name of the publication), only in the pattern If'al (إفعال).

a. All the names of the publications in this group were preceded by the letter hamzah al-qat' (همزة|القطع), which is the letter of the Alif. Followed are all the ways of the spelling, including the pronunciation of the letter hamzah. Example: Is.lam-Islam إسلام - إسلام =

b. All the name of the issue in this group is preceded by the letter hamzah al-qat' (هز (هزالقطع), which is the letter alif. Followed by all the ways, but must be dropped spelling hamzah. Examples: If.thar- Iftar = افطار - إفطار, Ikh.las-Ikhlas = اخلاص - إخلاص and I'.lan-I'lan = اعلان - إعلان = الخار

\section{Kata Kerja Bentuk V (tafa"ala)}

The V-form verb provides two types of word names in Bahasa Indonesia and Melayu, namely

1. Ism fa'il (the name of the perpetrator) only in the pattern mutafa"al (متفع).

a. The words in this group are mostly terms, so the spelling is retained according to the language of the source. Examples: Mu.ta.kal.lim - Mutakalim = متكلم - متكلم, Mu.ta.na.jis-Mutanajis

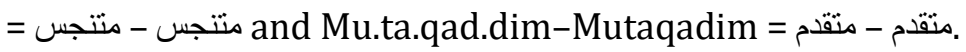

b. There are also words in this group that have changed the mention then the changes apply to the addition of the vowel letter in the final closed syllables. Example: Mu.ta.akh.khirMutakhir $=$ متاخير - متأخر.

2. Ism masdar (name of the issue) only in tafa'ul pattern (تفعل) 
a. Many belong to the common word. However, generally Indonesian and Malay speakers are not able to appropriately call it (according to the sound of the source language, namely in the letter marked with Syaddah), hence the error is a mistake, which is the removal of syaddah. Finally the corresponding word is spelled according to mentions in our society. The phrase is often added to the final closed syllable. The first sound trend. Example: Ta.kab.bur-Takabbur = تعبر تكبور, Ta.'aj.jub- Ta'ajjub = تعجوب - تعجب and Ta.'al.luq - Ta'aluq = تعلوق - تعلق.

b. As above and this is the tendency to mention the second sound. Examples: Ta.mad.dun-Tamadun = تمدون - تمدن ta.fak.kur-Tafakur $=$

c. As above and this is the tendency to mention the third sound. Example: Ta.'as.sub-Ta'asub = تعصب - تعصب and Ta.'aq.qulTa'akul = تعقول - تعقل.

Verb Form VI (tafa'ala)

The verb form VI provides two types of word names in Indonesia and Malay language, namely:

1. Ism fa'il (name of the perpetrator) only in the patternmutafa'il (متفاعل).

It israre, but it is also a term. This needs to be spelled according to its original spelling. Example: Mu.ta.wa.tir-Mutawatir = منواتر منواتر.

2. Ism masdar (name of the issue) only in the pattern tafa'ul (تفاعل).

a. Many became terms, so the spelling was preserved. Example: Ta.'a. ruf-Taaruf = تعارف, Ta.wa.du'-Tawaduk = تعارف, توفع - توفع -

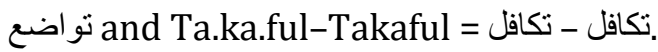

b. It is considered a common word, so it is still spelled according to the spelling of Arabic Malay. Plus the vocal letterwau on the final closed syllables. Example: Ta.da.rus-Tadarus = تدارس تداروس.

Verb Form VII (ift'ala)

This Verb Form VIIProvide three types of Word name in Indonesian and Malay, namely: 
1. Ism fa'il (the name of the perpetrator) drifting mufta'il pattern (مفتحل).

a. Maintained the way it was made because it became a term. Example: Muj.ta.hid-Mujtahid = مجتهد - مجتهـ

b. The final closed word becomes an open word, when the letter Hamzah at the end of the word that has been taking the house of ye should not be called clearly. Therefore, it needs to change its spelling a bit. Example: Mub.ta.di'-Mubtadi = مبندئ مبتدي.

2. Ism Maf'ul (name of the object) only in mufta'al pattern (مفتعل).

a. Although many in common words, but because it has been steady with its original spelling, then it continues to be retained. Example: Mu '. Ta. Mad - Mutamad = معتمد - معتمد

b. becoming a common word then is spelled with an alif-letter in the final closed syllables. Example: Mus.ta.jab-Mustajab = مستجب - مستجاب.

c. Being a common word then is spelled by changing the way to put hamzah, not on the letter wau, even separately with the house itself. Example: Mu'.ta.mar-Muktamar = مؤتمر - مؤتمر.

3. Ism masdar (name of the issue) only in the pattern ifti'al (افتعال).

a. Many words in this group consist of terms, although not elemental to Islamic terms, so the spelling needs to remain retained in the language of the source. Examples: Ij.ti.hadIjtihad = اجتهاد - اجتهاد, Ij.ti.ma'-Ijtimak = اجتماع - اجتماع and Ikh.ti.sas-Ikhtisas = اختص - اختصاص أن

b. The word term itself is not a term anymore. It is considered a common word and then is spelled according to its Arabic spelling. Example: Is.ti.lah-istilah = ايستيله - اصطلاح

c. The final closed syllables become open syllables if the letter of Hamzah at the end of the word is not clearly mentioned.It is necessary to change a slight spelling of the Latin. In Arabic spelling, the sound of hamzah is required to be returned. Example: Ib.ti.da- Ibtida' = ابتداء - ابتداء.

\section{Verb Form VIII (istaf'ala)}

This verb form VIIIprovidesthree types of word name in Indonesian and Malay language, namely: 
1. Ism fa'il (the name of the offender) only in the pattern mustaf'il (مستفعل), mustafil (مستفيل) and mustafill (مستفل)

a. For the pattern of mustaf'il, it is retained by its spelling. Example: Mus.ta.mi'-Mustamik = مستمع - مستمع.

b. For the pattern of mustafil which is the second letter in the verb the period of its lamp consists of the alif, maintained also the spelling. The letter yes there is original, not added. Examples: Mus.ta.hil- mustahil = مستحيل - مستحيل and Mus.ta.qim-Mustakim = مستقيم - مستقيم

c. For the pattern of mustafill, the second and third letter in the verb of period consists of the same consonant, the modified spelling by adding the letter ye to the final closed syllables. Example: Mus.ta.'id - Musta'id = مستعيد - مستعد.

2. Ism maf'ul (the Word object name) only in the pattern mustaf'al (مستفعل).

a. The words of the past verbs that all the letters of consonant remain in their spelling. Example: Mus.ta'.mal-Mustakmal = مستعمل - مستعمل

b. The word of the past verb of which the second letter consists of an alifletter changed by removing the alif in the final closed syllable. Example: Mus.ta.jab-Mustajab = مستجب - مستجاب.

c. The word of the past verb that the second and third letters consist of the same consonant letters changed by removing one of the same consonants. Example: Mus.ta.haqq-Mustahak $=$ = مستحق - مستحق.

3. Ism masdar (nouns of derivation) is only in the pattern istif'al (استفعال) and istif'alah (استفعالة).

a. If all of the working letters of the verb are consonant, then the istif'al pattern should be used. The spelling does not change immediately. Example: Is.tigh.far-Istighfar = استغفار - استغفار, Is.tin.ja'-Istinjak = استنجاء - استتجاء dan Is.tiq.rar-Istikrar = استقرار - استقرار

b. If the second letter in the past verb which consists of an alifletter (fi'l mu'tall), then the pattern istif'alah is used. The spelling does not change except the letter $t a$ '. It is time to change into $t a^{\prime}$ maftuhah. Example: Is.ti.kha.rah-Istikarah = 
استخارة - استخارة, Is. ti.qa.mah- Istikamah = استقامة - استقامة and Is.ti.ra.hah-Istirahat = استر احت - استراحة.

The results of this study in its entirety, in terms of Arab uptake that entered into Indonesian and Malay, can be said that it is very much absorbed and used in the daily speech for the Indonesian and Malay languages. WWhile the development of the two countries has established also Indonesian and Malay grammar and Arabic Malay (Jawi) script which more dominates the language. In addition, it is also found that the most widely used for ancient scholarly works such as manuscripts and other books are also based on Arabic or Jawi language and writings as a promotion of the deprecation of the language and an additional option in expressing knowledge and skill in the society of Nusantara.

The role of this Arabic language has been used in communicating from its high literary touch according its native speakers, including those used in Indonesia and Malaysia. Even this language is absorbed into a language whose use is not merely an intermediate language but also a language of science, religion, literature, economics, law, arts and culture developed by the community which in turn can reflect their civilization trend.

Indonesian and Malay continue to evolve in parallel with the change of Arabic script, together with its writings. If studied deeply, there are many Arabic words received and absorbed as complementary language in Indonesian and Malay. Even in the record of this study,it is estimated that more than 2.200 words have been absorbed and adopted in the speech of this society both orally and in writing.

Therefore, it is important to understand or to know the methods of acceptance of languages that enter the local language of the Arabic words to facilitate their use in the recipient language, either for the purpose of meaning or to add Synonymous words in the vocabulary or the usefulness of oral or written communication for Bahasa Indonesia and Malay.

\section{Conclusion}

The growing Islamic religious presence in Southeast Asia has made Arabic as an important language even the point of the decline of 
Indonesian and Malay language through the existing absorption. In addition, Islam also affects the Malay script which generally consists of 30 letters drawn from the Arabic Hijaiyah letter, but there are additional letters that are drafted to fulfill the needs of the local language sound symbols, namely ca, nga, $p a, g a, n y a, v a$ and ye (ye not dotted), so that it makes the whole letter letters 37 characters. The appearance of the use of Arabic Malay (Jawi) in Nusantara in writing or speaking has become an important medium in language and literature. How many Arabic words are absorbed into the Indonesian and Malay language so that now with various styles and its own style, instead become the language of the book on science and communication in the region until now.

While the existence of Latin writing appears because of the absorption of foreign languages and other European language, then the use of the language a little overwhelming can also color the writings and sayings of Arabic Malay written from the words of Arabic removals in the Latin writings itself and Arabic, Indonesian and Malay. Therefore, this study may be able to lift the dignity and language of the Islamic community in the archipelago especially in Indonesia and Malaysia as an instrument of oral and written communication, in addition to the function of the language is also expected to strengthen its role in the midst of the life of various Muslims as a lighting torch in realizing its cultural and dignified civilization from time to time.

\section{Bibliography}

Tim Penyusun. 1986. Al-Qur'an dan Terjemahannya. Jakarta: Departemen Agama Republik Indonesia.

Amat Juhari Moian. 1996. Perancangan bahasa: Sejarah aksara Jawi. Kuala Lumpur: Dewan Bahasa dan Pustaka.

Asmah Haji Omar. 2008. Ensiklopedia bahasa Melayu. Kuala Lumpur: Dewan Bahasa dan Pustaka.

Bausani, Alessandro. (T.th). Catatan mengenai kata-kata Parsi dalam bahasaMelayu-Indonesia. Hamid Algar dan Bukhari Lubis (pent.). Bangi: IBKKM, Universiti Kebangsaan Malaysia.

Fakulti Bahasa dan Komunikasi 2011/2012. Buku panduan akademik program Ijazah Sarjana Muda. Tanjong Malim: Fakulti Bahasa dan Komunikasi, UPSI. 
Dewan Bahasa, Daftar kata bahasa Melayu rumi-sebutan-Jawi (edisi kedua). 2008. Kuala Lumpur: Dewan Bahasa dan Pustaka.

Ensiklopedi kebahasaan Indonesia.2009. Jld 1-4. Bandung: Angkasa.

Hamdan Abdul Rahman. 1999. Panduan menulis dan mengeja Jawi. Kuala Lumpur: Dewan Bahasa dan Pustaka.

Hamdan Abdul Rahman. 2014. Panduan menulis dan mengeja Jawi edisi kedua. Kuala Lumpur: Dewan Bahasa dan Pustaka.

Hashim Musa. 1999. Sejarah perkembangan tulisan Jawi. Kuala Lumpur: Dewan Bahasa dan Pustaka.

Himpunan Kertas Kerja. 2011. Persidangan kebangsaan tulisan Jawi kali ke-dua. Kuala Lumpur: UPSI \& PNM.

Indonesia indah "aksara" (T.th). Jld 9. Jakarta: Yayasan Harapan Kita BP3/TMII.

Ismail Hussien. 1984. Sejarah pertumbuhan bahasa kebangsaan kita. Kuala Lumpur:Dewan Bahasa dan Pustaka.

Jones, Russell (ed.umum). 2008. Loan-words in Indonesian and Malay. Jakarta: KITLV dan Yayasan Obor Indonesia.

Kamus besar bahasa Indonesia. 1988. Jakarta: Departemen Pendidikan dan Kebudayaan Republik Indonesia.

Kamus Dewan (edisi keempat).1989. Kuala Lumpur: Dewan Bahasa dan Pustaka.

Makmur Haji Harun dan Muhammad Bukhhari Lubis. 2015. Analisis penggunaan serapan Arab dalam bahasa Indonesia dan Melayu sebagai bahasa komunikasi: Satu kajian awal. Makalah Seminar Internasional di Universitas Islam Malang.

Manja Mohd. Ludin dan A. Suhaimi Hj. Mohd. Nor. 1995. Aspek-aspek kesenian Islam. Kuala Lumpur: Dewan Bahasa dan Pustaka.

Matlob. 2002. Pandai Jawi. Shah Alam: Cerdik Publications Sdn. Bhd.

Mohd Hussein Hj. Baharuddin. 2010. Sistem tulisan Jawi. Serdang: UPM Holdings Sdn. Bhd.

Mohd Nasir Abdullah. 2006. Cerdik Jawi: Tahun 5 dan 6 KBSR. Shah Alam: Cerdik Publications Sdn. Bhd.

Muhammad Bukhari Lubis dan Ali Haji Ahmad. 2006. Transliterasi kata ArabParsi-Turki. Kuala Lumpur: Utusan Publications \& Distributors Sdn. Bhd.

Muhammad Bukhari Lubis, Makmur Haji Harun dan Alizah binti Lambri. 2014. Jawi warisan warga Alam Melayu. Tanjong Malim: Penerbit Mentari. 
Noor Nabeela. 2005. Cerdik Jawi: Tahun 3 KBSR.Shah Alam: Cerdik Publications Sdn. Bhd.

Razliza binti Abd. Rahman. 2006.Cerdik Jawi: Tahun 4 KBSR. Shah Alam: Cerdik Publications Sdn. Bhd.

Syed Muhammad Naguib al-Attas. 1972.Islam dalam sejarah dan kebudayaan Melayu.Bangi: Universiti Kebangsaan Malaysia.

Syed Nurul Akla Syed Abdullah dan Adi Setia Mohd. Dom (terj). 2010. Pengembaraan Ibnu Battutah. Kuala Lumpur: Institut Kefahaman Islam Malaysia (IKIM).

Tan Boon Chye. 2009. Cerdik Jawi. Shah Alam: Cerdik Publications Sdn. Bhd.

T. Iskandar. 1995. Kesusastraan klasik Melayu sepanjang abad. Bandar Seri Begawan: Jabatan Kesuasteraan Melayu, UBD.

Za’ba. 1949. Daftar ejaan Jawi. Tanjong Malim: Pejabat Karang Mengarang Sultan Idris Training College.

Za'ba. 2009. Rahsia ejaan Jawi: Edisi ejaan rumi. Kuala Lumpur: Dewan Bahasa dan Pustaka.

Zalilah Ahmad. 2005.Cerdik Jawi: Tahun 2 KBSR. Shah Alam: Cerdik PublicationsSdn. Bhd.

Zarina Sidek dan Siti Ramilah Abu Najar. 2005. Cerdik Jawi: Tahun 1 KBSR. Shah Alam: Cerdik Publications Sdn. Bhd.

http://www.google.com

http://www.artikata.com 
180 | AJIS, Vol. 4 No. 2, November 2019 